\title{
Area-based historical modeling of the effects of the river bank regulation on the potential abundance of eleven mosquito species in the River Danube between Hungary and Slovakia
}

\author{
Attila Trájer, ${ }^{1,2 *}$ Kinga Farkas-Iványi, ${ }^{3,4}$ Judit Padisák, ${ }^{1,2}$ \\ ${ }^{1}$ University of Pannonia, Department of Limnology, H-8200 Veszprém, Hungary; ${ }^{2}$ MTA-PE Limnoecology Research Group, Egyetem \\ utca 10, H-8200 Veszprém, Hungary; ${ }^{3}$ Corvinus University of Budapest, Faculty of Landscape Architecture, Villányi út 29-43, H-1118 \\ Budapest; ${ }^{4}$ Danube Research Institute, MTA Centre for Ecological Research, Karolina út 29, H-1113 Budapest, Hungary \\ *Corresponding author: atrajer@gmail.com
}

\begin{abstract}
The construction of reservoirs and hydropower plants was accelerated in the past century due to the increasing aridity in many parts of the world. The effect of water regulations on the abundance of mosquito vectors is controversial. In this paper, the habitat preference of mosquitoes was investigated based on a 30-years long collection of the mosquito data in Hungary, military maps and satellite images. Three time phases of the analyzed section in the Danube River were analyzed in order to characterize the impact of human influence on mosquito habitats: the semi-natural phase, the post channelization phase and the post hydropower dam state. Geographical data referring to the years 1790, 1820,1830,1870, 1946 and 1955 were based on military maps, whereas the years 2004 and 2013 were analyzed by satellite imagery. The Amoros-like eupotamon A - plesiopotamon line represents an increasing gradient of habitat-suitability for mosquitoes. The habitat-preference of different mosquitoes to the Amoros-classified water habitats was based on a monographic collection data. This dataset contains the collecting and trapping results from the 1960s to the early 2000s in Hungary. We found that human-induced changes had prolonged impact on mosquito-suitable habitats, although the effect can be different for diverse mosquito species. The increase of the evenness of the mosquito fauna was seen since the mid- $20^{\text {th }}$ century, after the primary river regulation. The increasing areal extension of relatively warm and nutrient-rich water habitats had positive effects on the more rare members of the mosquito fauna, such as the potential malaria vector mosquito Anopheles algeriensis according to the model results. Summarizing, we found a strong, positive link between anthropogenic interventions and the mosquito diversity in water ecosystems.
\end{abstract}

Key words: River regulation; limnoecology; mosquito vectors.

Received: July 2015. Accepted: November 2015.

\section{INTRODUCTION}

The construction of reservoirs and hydroelectric power plants (HPPs) in the last century showed a huge increase, strongly influencing the hydrology of natural fluvial systems (Christensen et al., 2004) and causing an extension of large flooded areas and artificial wetlands, which are excellent potential habitats for mosquitoes. While the mankind modified the natural hydrosystems, global warming favored the expansion and increasing of insect populations by changing the length of vegetation period and decreasing the severity of winter throughout Europe. Furthermore, climate change and the increased cargo transport facilitated the migration of arthropods, among them mosquito vectors (Benedict et al., 2007; Githeko et al., 2000; Kovats et al., 2001). The effect of river regulation and other hydromorphological modifications such as the disturbance of wetland habitats on the temporal change of mosquito habitats has been a relatively neglected topic. Cailly et al. (2011) demonstrated that the distribution of some Culex and Anopheles species was mainly driven by the repartition of their specific breeding habitats. The landscape determinants of mosquito larval habitats vary from species to species. For example, the primary malaria vectors in sub-Saharan Africa generally utilize small temporary habitats as breeding sites. Different mosquito species prefer various breeding sites, e.g. Aedes albopictus and Aedes aegypti are typical container-breeding mosquitoes utilizing mostly artificial breeding sites created by human activities such as tires, catch basins, bins, various rubbish, and plant saucers. In contrast, the studied mosquitoes prefer or primarily use oxbow lakes and other natural shallow standing waters. It was assumed that landscape diversity highly affects the mosquito density (Overgaard et al., 2003). However, since the identification of mosquito larval habitats over large geographic areas requires great efforts, several remotesensing techniques (Brown et al., 2008) were developed, including drones and satellite images (Mushinzimana et al., 2006).

Though the main phase of the river regulations occurred in Europe from the 1800s to the mid-1900s, more 
recently serious efforts were made to constructing HPPs, dams and drainage systems in the developing countries, e.g. China (Dudgeon, 1995), Africa and South-America (Nilsson et al., 2005). There is wide consensus about the effects of river regulation and the decline of wetlands on the changing patterns of both the mosquito inhabited habitats and the occurrence of mosquito-borne diseases as it has happened in case of the Upper Mississippi Valley (Ackerknecht, 1945). However, the role of the pesticides and the insecticide treatments were not well understood. For example, malaria was a native disease in Hungary until the middle of the $20^{\text {th }}$ century, despite that the river minor regulations started in the 1820 s, with the main part of the regulations performed between 1886 and 1896 (Töry, 1952). Between 1933 and 1943, the countrywide case number of malaria was estimated in 10.000-100.000 per year (Szénási et al., 2003). The application of the pesticide dichlorodiphenyltrichloroethane (DDT), coupled with serious public health interventions, finally led to the eradication of the prevalent focuses by 1956 (Szénási et al., 2003; Lörincz, 1937). Prior to the 1950s, in Hungary Anopheles atroparvus, Anopheles maculipennis and Anopheles messeae were the plausible potential vectors of the Plasmodium parasites (Szénási et al. 2003).

Despite the river regulation, mosquito-borne diseases other than malaria are emerging diseases in Hungary. West Nile fever and dirofilariasis caused by Dirofilaria repens and Dirofilaria immitis became endemic over the last two decades in the Carpathian Basin (Fok, 2007, Krisztalovics et al., 2008). Additionally, Aedes mosquitoes, the primary vectors of Dengue and Chikungunya fever, are widely present in the Mediterranean Basin (Spain, France, Italy, Albania, Greece, Bosnia and Herzegovina) and the southern neighboring countries of Hungary, such as Slovenia, Croatia and Serbia (Klobučar et al., 2006; Scholte and Schaffner, 2007). Climate change can facilitate the spread of vector Aedes species in the Carpathian Basin and many other parts of Europe. According to regional climate models, the climate of the Carpathian Basin in the 2071-2100 period is expected to become wetter and milder in winter season (Bartholy et al., 2007, 2008) favoring the colonization of invasive mosquito species. Mosquitoes are strongly related to the river bank systems and such a simple geographic factor as the distance from the river may determine the risk patterns of the acquiring mosquitoborne diseases, as in the case of the West Nile fever in 2008 documented in Hungary (Trájer et al., 2014). Since the adult female mosquitoes have good flying ability, the expansion of the mosquito species can be relatively rapid. Mosquitoes in general require silent, relatively warm environments for their reproduction and development. These conditions are not those typically found in the eupotamon streams of the temperate areas of Europe. The conditions of the parapotamon and plesiopotamon streams are more suitable for mosquitoes. It remains an open question whether the river regulation facilitated or impaired the habitat templates of the potential mosquito vectors. Since the construction of water reservoirs and hydroelectric power plants is still increasing and the naturalization of the river banks has also started, it is an urgent task to study the potential effect of these changes and evaluate the possible effects on the mosquito populations like Anopheles maculipennis or Anopheles atroparvus.

In Western Hungary, prior to extensive regulations, the Szigetköz floodplain was a periodically restructuring alluvial anabranching channel system (Guti et al., 2010). The rejuvenation of the vegetation was twice as intensive in its upper section as in its lower area (Farkas-Iványi and Guti, 2013). The first major, but indirect human influence affected the area after 1812 (Hohensinner et al., 2004, 2005, 2011). With the beginning of the regulation of the Austrian part of the Danube, vast sediment flux reached the alluvial plain of the Szigetköz part of the Danube, lifting the river bed. The second, direct anthropogenic effect was the confining of the Danube into dams which reached its peak with the formation of the artificial main channel at the end of the $19^{\text {th }}$ century. The third human influence was represented by the building of the Gabčíkovo-Nagymaros Dams (19771992), which caused the diversion of the $90 \%$ of water off the old riverbed (Fürst, 2006). The water replacement system was completed by 1995 however, in the Szigetköz, the main channel received only the $15 \%$ of the river water supply, causing a drastic decrease in the water level. The modified hydro-geomorphological processes lead to terrestrialization, formation of abandoned channels and significant decline of ecological rejuvenation in the floodplain (Farkas-Iványi and Guti, 2014).

The main objective of this work is to assess the consequences of the river regulations and construction of water power plants on the abundance of mosquito vectors in the Danube River, in Hungary. The long-term changes will be evaluated by comparing the original function and changing in the Szigetköz territory by using historical maps and reconstructing the change of the relative number of mosquito larvae during the last 200 years. The adopted method was based on the weighting of the past and present aquatic habitats with the relative habitat-preference value of the studied mosquitoes.

\section{METHODS}

According to the above described history, three time phases of river regulation were analyzed in order to categorize the impact of human influence on the river habitat and mosquito changes. The three phases include the seminatural phase (maps 1790, 1820, 1830, and 1870), the post channelization phase (maps 1946, 1955 and 1986) and the post hydropower dam state $(2004,2013)$. 


\section{The studied mosquito species}

Different Anopheles, Aedes and Culex mosquito species with different relative countrywide dominance/ frequency values (D) according to the dataset of Tóth (2004) were considered in this work. These include: Anopheles algeriensis Theobald $1903(\mathrm{D}<0.1 \%)$, Anopheles atroparvus Van Thiel $1927(\mathrm{D}=0.11 \%)$, Anopheles claviger Meigen $1804(\mathrm{D}=1.48 \%)$, Anopheles hyrcanus Pallas $1771(\mathrm{D}=0.03 \%)$, Anopheles maculipennis Meigen 1818 ( $\mathrm{D}=2.85 \%)$, Anopheles messeae Falleroni 1926 $(\mathrm{D}=0.38 \%)$, Aedes cinereus Meigen 1818, Aedes rossicus Dolbeskin and Gorickaja $1930(\mathrm{D}=0.57 \%)$, Aedes vexans Meigen 1830 ( $\mathrm{D}=15.12 \%)$, Culex modestus Ficalbi 1890 $(\mathrm{D}=3.26 \%)$ and Culex pipiens pipiens Linnaeus 1758 $(\mathrm{D}=15.15 \%)$. Each modeled mosquito species are native in the studied area. An. atroparvus, An. hyrcanus and An. algeriensis are thought to be potential vector of Plasmodium species in the Mediterranean (Jetten and Takken, 1994); An. maculipennis and An. messeae are also important malaria-vectors. Culex pipiens is one of the potential vectors of Dirofilaria immitis and avian malaria in Hungary (Zittra et al., 2015).

\section{Definitions of the aquatic habitat types in the Szigetköz floodplain}

In this study, 28 historical maps provided information on the change of the river morphology and the historical areas of the floodplain basin of Szigetköz. The georeferencing of the historical maps of the area prepared in 1790, 1820, 1825, 1830, 1870, 1946, 1955, 1986, 2004 and 2013 was performed in ArcGIS 10.0, by selected landmarks, both historical and still existing. Second polynomial (Affine) transformation was used between the temporarily different raster layers (Cajthaml, 2013).The typology of the habitat analyses was based on the functional classification by Amoros et al. (1987). The Amoros-classification takes into account the flow velocity of the branches and the intensity of lateral connectivity between the main channel side arms and backwaters. We selected this topological classification system because it provides a single morphological identification of the historical stages allowing a comparison of the recent state without requiring the knowledge of the long-term changes in water chemistry and other factors. Changes in the water flow and lateral connectivity from the main channel (the eupotamon A) to the paleopotamon stage are in good correspondence with the main requirements of mosquito species. The determined branches were signed by consequent coloring. We calculated the area of the georeferred and colored branches (Fig. 1).

With the construction of the Gabčíkovo-Nagymaros Waterworks, water replacement system cascade-like sections were included into the former main branches (mainly replacing the earlier eupotamon B). These modifications increased the water level, creating a system of numerous reservoirs. In this paper, we refer to these branches as cascadepotama. Since these branches have a permanent, but relatively low flow, the corresponding habitats can be classified between the plesiopotamon and eupotamon B, with low water level. In the successive analysis we will handle the cascadepotamon as the transient stage between the two habitats, but it is important to note that this assumption is made only as a practical approximation.

Finally, the number of the transition numbers of the habitats of given potama (e.g., paleopotamon in 1825 to plesiopotamon in 1830) were counted between each studied neighboring years. The numbers of transitions were normalized according to the length of the periods between the adjacent years.

We assumed that the collection record and long-term evolution of the different water types can reflect the effects of the different physical and chemical conditions, as well as the level of the predatory pressure to the larvae of mosquitoes. This was referred to as the relative value of mosquito suitability. Further, the surface of a given water body was assumed to be linked to the potential number of larvae. Larvae, breathing through spiracles or a siphon, come to the surface frequently and spend most of their time feeding on the surface microlayer of the stems and leaves of the submerged vegetation and floating-leaf plants.

The characterization of the habitat-preference of the different mosquitoes was based on the countrywide monographic collection data of The fauna of mosquitoes in Hungary (Diptera: Culicidae) by Tóth (2004). This faunistic monograph contains the collection data of the breeding sites, the seasonality and the habitat-preference data of the native mosquitoes of Hungary based on investigations carried out since the 1960s (cf. Tab. 1). The monograph separately lists the collecting data of larvae, pupae, and the adult male and female mosquitoes. The habitats were associated with the number of breeding sites where the larvae of a given mosquito species were collected. The monograph contains the collection data of 198066 larvae of 48 different mosquito species. The indicated countrywide dominance/frequency values of the mosquito larvae (D) were also gained from Tóth (2004). Mosquito larvae were captured by net collection at 1) the waterline; 2) from the surface of submerged stems and shoots; and 3) from the sediment (Tóth, 2004).

The data regarding the larvae of mosquitoes were used according to the following standpoints in the characterization of the water bodies:

1) Larvae are the most water-bound and flightless ontogeny forms of mosquitoes; compared to adults, they are easier to locate.

2) The collection of larvae is the less selective proce- 
dure; the selective attractiveness of traps or human bodies does not play any role in the case of larvae, ensuring a good represent activity in contrast to imagoes.

3) We considered the number of the breeding sites in the different aquatic habitats as an indicator of the habitat preference of the studied mosquito species. The weight $(w)$ of the different aquatic habitat types was derived from the number of the breeding habitats in the countrywide summary of the mosquito occurrences. It can be assumed that if a mosquito species $(A)$ was more frequently collected in a habitat type than another $(B)$ species, then $A$ prefers more that given habitat than $B$. The $w$ is coincident with the values of Tab. 2 .

Floodplain and floodplain pool, the medium-sized river, the small lake reservoir, the types of artificial small lakes of standing waters, the other types of small artificial lakes of standing waters, the littoral shallow lakes, the litoprofundal shallow lakes, the artificial swamps and standing waters, the marsh-type natural standing waters, the natural or artificial duckweed covered puddles, swamps and small marshes can be classified with the Amoros-scheme of water classification (Tab. 3. Tömpöly's the special Hungarian name of a habitat type which is defined as a minor permanent water body derived e.g. from the pits left behind of the constructions of dams (small, shallow water basins vegetated by aquatic submersed or floating macrophytes, which are perennial and do not dry out regularly).

The correspondence between the aquatic habitats classified by using the Amoros-like classification and the mosquito-collecting habitats identified by Tóth (2004) (Tab. 3) was somewhat problematic. While the first is a regional scale system mainly based on topographical characters, the latter is a subsidiary classification system based on the habitats colonized by the mosquito larvae. Some of the aquatic habitats classified by Amoros et al. (1987) do not occur in the studied area (e.g., cold springs) or are not quantifiable on an aerial basis (e.g., the technotel-
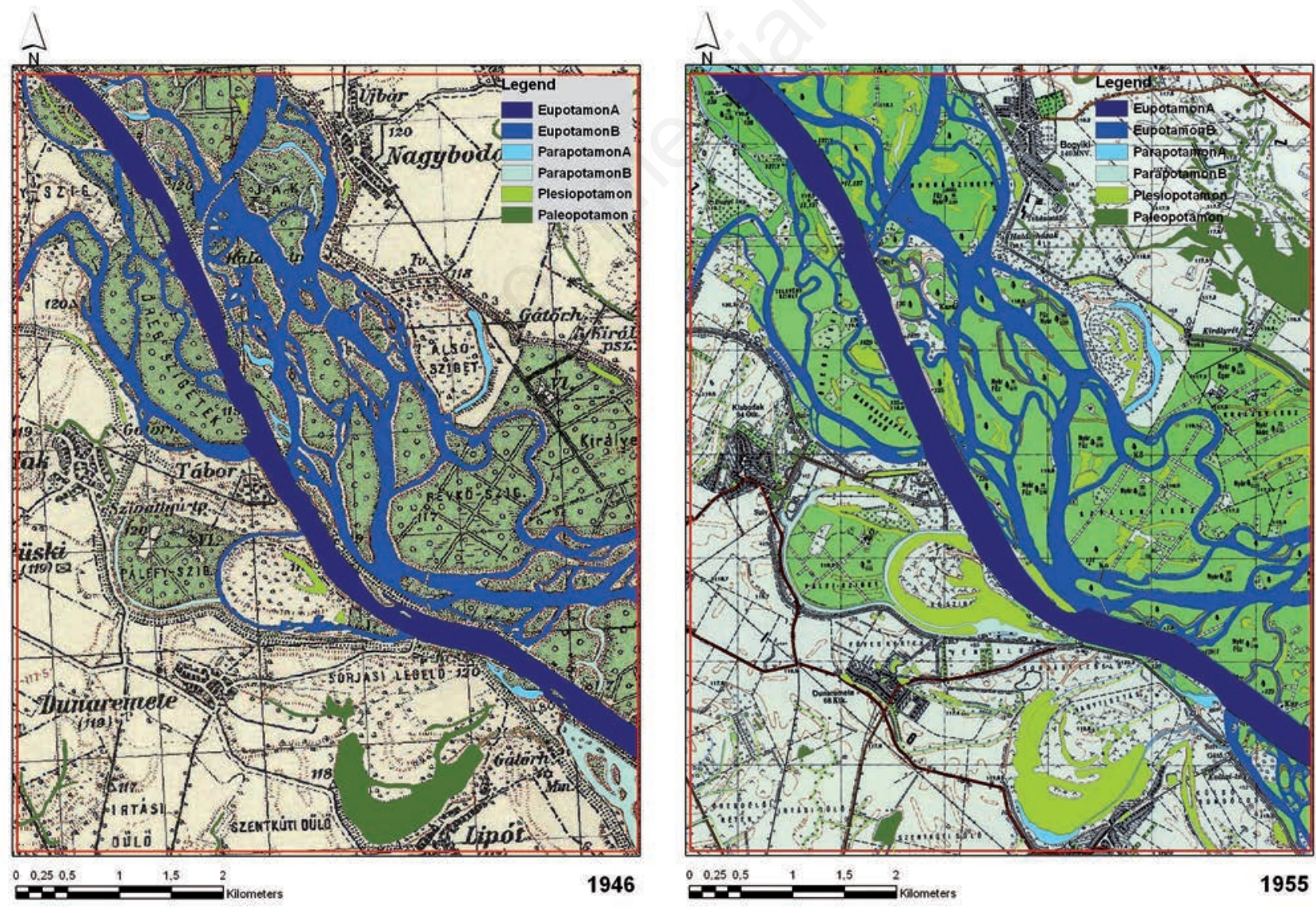

Fig. 1. The spatial subdivision of aquatic habitats in the studied area in 1946 and 1955. Light green field marks the floodplain forest; the white background shows the arable lands. Dark blue, eupotamon A; blue, eupotamon B; light blue, parapotamon A; pale blue, parapotamon B; neon green, Plesiopotamon; dark green, Paleopotamon. 
mata/phytotelmata habitats, which would be important, but the quantification has yet been impossible).

Although paleopotama and plesiopotama are isolated water bodies with only occasional connection with the main channel, paleopotama are shallower habitats mainly with a single littoral part, whereas plesiopotama have a profundal riverbed part. These differences were also reflected in the data collected by Tóth (2004). It is important to highlight that the eupotamon-parapotamon-plesiopotamon-paleopotamon sequence coincides with the progression of the river bank succession, and with the parallel increasing nutrient content and temperature of the water and the decrease of the water flow and shallowing of the water body.

To rank the suitability of the habitats in term of the mosquitoes we also used the data reported in Tóth (2004). The typology of mosquito habitats is based on the size of the surface water, the depth of the riverbed and the connecting branches, and the abundance of the macro-vegetation. The correspondence between the topology systems by Amoros et al. (1987) and Tóth (2004) was based on the hydrological similarities of the water bodies (Tab. 3).

Eupotamon A, B and the parapotamon A and B waters are relatively cold, deep, nutrient-poor and flowing envi-

Tab. 1. Number of the sites where the mosquito larvae were collected in Hungary according to the data reported by Tóth (2004).

\begin{tabular}{lccccccccccc} 
Species & FP & MR & SL & AS & OS & LS & LP & AW & MN & TN & TA \\
An. algeriensis & - & - & - & - & - & - & - & - & 4 & - & - \\
An. atroparvus & 2 & - & 1 & - & 2 & - & 13 & 10 & 72 & 7 & - \\
\hline An. claviger & 2 & - & 3 & 17 & 4 & - & 175 & 53 & 297 & 163 & 24 \\
An. hyrcanus & 9 & - & 3 & 19 & 2 & - & 1 & 8 & 23 & 3 & 7 \\
\hline An. maculipennis & 9 & - & 20 & 21 & 16 & - & 318 & 28 & 550 & 267 & 33 \\
An. messeae & 6 & - & 4 & 1 & 3 & 1 & 29 & 13 & 110 & 24 & 13 \\
\hline Ae. cinereus & 4 & - & 6 & 14 & 4 & - & 164 & 33 & 269 & 192 & 11 \\
Ae. rossicus & - & - & - & - & 1 & - & 17 & 1 & 26 & 5 & - \\
\hline Ae. vexans & 4 & - & 16 & 19 & 10 & - & 245 & 54 & 422 & 221 & 31 \\
Cx. modestus & 7 & 4 & 11 & 31 & 14 & - & 330 & 69 & 312 & 46 & 10 \\
\hline Cx. pipienspipiens & 11 & - & 11 & 6 & 32 & 1 & 304 & 85 & 594 & 387 & 54 \\
\hline
\end{tabular}

FP, floodplain and floodplain pools; MR, medium-sized rivers; SL, small lake reservoirs; AS, artificial small lakes with standing waters; OS, other types of small artificial lakes with standing waters; LS, littoral shallow lakes; LP, litoprofundal shallow lakes; AW, artificial swamps and standing waters; MN, marsh-type natural standing waters; TN, Tömpöly-type; TA, natural waters, Tömpöly-type artificial waters.

Tab. 2. Number of the collected larvae (corresponding to $w$ ) in the different habitats (Tab. 3) according to Tóth (2004; Tab. 1).

\begin{tabular}{|c|c|c|c|c|c|c|}
\hline Habitat type/species & An. alg. & An. atr. & An. cla. & An. hyr. & An. mac. & An. mes. \\
\hline eupotamonA & 0 & 2 & 2 & 9 & 9 & 6 \\
\hline eupotamonB & 0 & 1 & 1 & 4.5 & 4.5 & 3 \\
\hline parapotamonA & 0 & 2 & 2 & 9 & 9 & 6 \\
\hline parapotamonB & 0 & 1 & 1 & 4.5 & 4.5 & 3 \\
\hline plesiopotamon & 0 & 5.33 & 49.75 & 6.25 & 93.75 & 7.6 \\
\hline paleopotamon & 4 & 29.67 & 134.25 & 10.25 & 219.5 & 40 \\
\hline bypass channel & 0 & 2 & 2 & 9 & 9 & 6 \\
\hline cascadepotamon & 2 & 15.33 & 67.63 & 7.38 & 112 & 21.5 \\
\hline Habitat type/species & Ae. cin. & Ae. ros. & Ae. vexans & Cx. mod. & Cx. pip. & \\
\hline eupotamonA & 4 & 0 & 4 & 7 & 11 & \\
\hline eupotamonB & 2 & 0 & 4 & 3.5 & 5.5 & \\
\hline eupotamonA & 4 & 0 & 4 & 7 & 11 & \\
\hline parapotamonB & 2 & 0 & 4 & 3.5 & 5.5 & \\
\hline plesiopotamon & 47 & 9 & 304 & 96.5 & 70.8 & \\
\hline paleopotamon & 126.25 & 10.67 & 182 & 109.25 & 280 & \\
\hline bypass channel & 4 & 0 & 4 & 7 & 11 & \\
\hline cascadepotamon & 64.13 & 5.33 & 93 & 56.38 & 142.75 & \\
\hline
\end{tabular}


ronments, which are almost unsuitable for Aedes, Anopheles and Culex species. This is clearly reflected in the countrywide data collected by Tóth (2004). Eupotamon and parapotamon water bodies correspond to the floodplain, floodplain pool and medium-sized river environments. In contrast, plesiopotamon and paleopotamon habitats provide a relatively warm, shallow, calm and nutrient-rich environment, which is essential for mosquitoes (Tab. 3).

The habitat preference of the mosquitoes according to the number of larvae collection (Tóth, 2004) reflects the classical belief that the larvae of Anopheles, Aedes and Culex prefer marshes, swamps and backwaters. Many species of larvae were mainly found in plesiopotamon and paleopotamon waters (An. claviger, An. maculipennis, Ae. rossicus, Ae. cinereus, Ae. vexans, Cx. modestus and $C x$. pipiens pipiens). The larvae of Anopheles algeriensis were found only in paleopotamon-like habitats. The larvae of An. atroparvus, An. messeae and, particularly of An. hyrcanus are known in a larger numbers of water types, including colder and faster flowing potamon types.

The habitat suitability-weighted area (HSWA) was calculated by the multiplication of the area of the water body within the grid and the number of occasions in which the larvae of the given mosquito species were collected by Tóth (2004) from the corresponding water types.

where

$$
H S W A=A w
$$

$A=$ area of the water body within the grid; $w=$ the habitat-related number of larvae according to Tóth (2004).

\section{The calculation of the evenness}

Species evenness $(E)$ quantifies how equal the community is numerically. Normally, the basic data of the calculation process is the relative abundance of a species and the number of the species (S). In this study, the HSWA value was instead used to approximate the relative abundance of the species within the population according to the Shannon-equation. Species evenness is computed as:

$E=\frac{\mathrm{H}^{\prime}}{\operatorname{lnS}}$

where

$H^{\prime}=$ Shannon-index (Eq. 3);

$S=$ number of the species (it is fixed; $n=11$ ).

$H^{\prime}$ is calculated as:

$$
\mathrm{H}^{\prime}=-\sum_{i=1}^{S} p_{i} \ln p_{i}
$$

where

$S=$ number of the species (it is fixed; $n=11$ )

$p_{i}=$ the proportion of the individuals of a species $i$, which is approximated and replaced with the corresponding HSWA value.

\section{RESULTS}

\section{The change of the weighted areal suitability of different mosquitoes}

The HSWA value is not equivalent to the abundance or the proportion of a mosquito species in the mosquito fauna,

Tab. 3. The correspondence between riverbed types and the aquatic habitats.

\begin{tabular}{ll} 
Habitat types & Trapping habitats of mosquitoes according to Tóth (2004) \\
eupotamonA & Floodplain and floodplain pool \\
\hline eupotamonB & Floodplain and floodplain pool \\
\hline parapotamonA & Medium-sized river \\
\hline parapotamonB & Floodplain and floodplain pool \\
plesiopotamon & Floodplain and floodplain pool \\
& Small lake reservoir \\
& Types of artificial small lakes of standing waters \\
& Other types of small artificial lakes of standing waters \\
& Littoral shallow lake \\
& Litoprofundal shallow lake \\
\hline paleopotamon & Artificial swamps and standing waters \\
& Marsh-type natural standing waters \\
& Tömpöly-type natural waters \\
& Tömpöly-type artificial waters \\
cascadepotamon & Transition between EuB and ParB (mid water-level) \\
& Transition between EuA and EuB (high water level) \\
& Transition between EuB and Plesiopotamon (low water level) \\
\hline nulpotamon & Drylandin a holm after of before the formation of a water body \\
\hline
\end{tabular}


but it is an area-based index, which can approximate the abundance of a mosquito species according to the suitability of an area as habitat. The relatively warm, shallow and nutrient-rich riverbed types are preferred by the different mosquito species. However, as shown in Fig. 2, there are notable differences between the habitat preferences of the species.

The results of the mosquito-suitability modeling of the habitats reflected the consequences of the antropogenic riverbed transformations (Figs. 3 and 4). However, the results varied species by species according to the differences in habitat preferences. The results of the modeled runs showed three local minima for the species Ae. cinereus, Ae. vexans, An. claviger, An. atroparvus and An. messeae in 1830, 1946 and 1986. The weighted areas of Cx. pipiens pipiens showed two major local minima in 1946 and 1986. An. algeriensis and An. maculipennis showed two major local minima in 1946 and 1986, and a minor in 1830. Local minima were also apparent for An. hyrcanus and Cx. modestus in 1830, 1946 and 2004. A major local minimum was found for Ae. rossicus in 1830.

An. atroparvus and An. algeriensis showed the greatest HSWA values in 1790, 1955 and 2013. Similar local maxima were found for An. algeriensis, An.claviger, Ae. cinereus, Ae. rossicus, Ae.vexans and Cx. modestus in 1790, 1955 and 2013. Ae. maculipennis and Cx. pipiens showed a largely decreasing trend during the studied years. The fluctuation of the maxima of An. messeae and
An. hyrcanus showed individual patterns (Figs. 3 and 4).

The modeled mean area-based suitability index proportion of the mosquito species showed the dominance of Cx. pipiens pipiens (\%HSWA: 42.2) and An. maculipennis (\%HSWA: 26.7) in the mosquito fauna (Fig. 5). A few species showed intermediate \% mean $H S W A$ values in the studied area, namely Ae. vexans (7.5), Cx. modestus (6.6), Ae. cinereus (5.3), An. claviger (5.2), An. messeae (2.4) and An. hyrcanus (2.1). The \%HSWA value of the most notable potential malaria-vector mosquito An. messeae ranged between 1.9 and 2.6, showing relatively modest variations (SD: 0.26; Fig. 5).

The changes in the evenness values showed a significant increasing trend after the river regulation until the 1950s $(\mathrm{P}=0.014)$ (Fig. 6). Before the river regulation (1790-1870) the mean evenness was 0.62 , whereas after the river regulation (1946-2013) the mean value was 0.74 . The construction of the hydropower plant did not caused significant changes in the evenness values.

During nearly a 200-year period, the river streams underwent important modifications, showing changes in their attribution to specific stream types or even disappearing or forming in other zones of the studied area (Farkas-Iványi and Trájer, 2015). Since the time periods between dates of the maps were different, the number of stream transitions was calculated for identical long periods. The frequency of the standardized transitions per year calculated to the half periods between 1805 to 2008

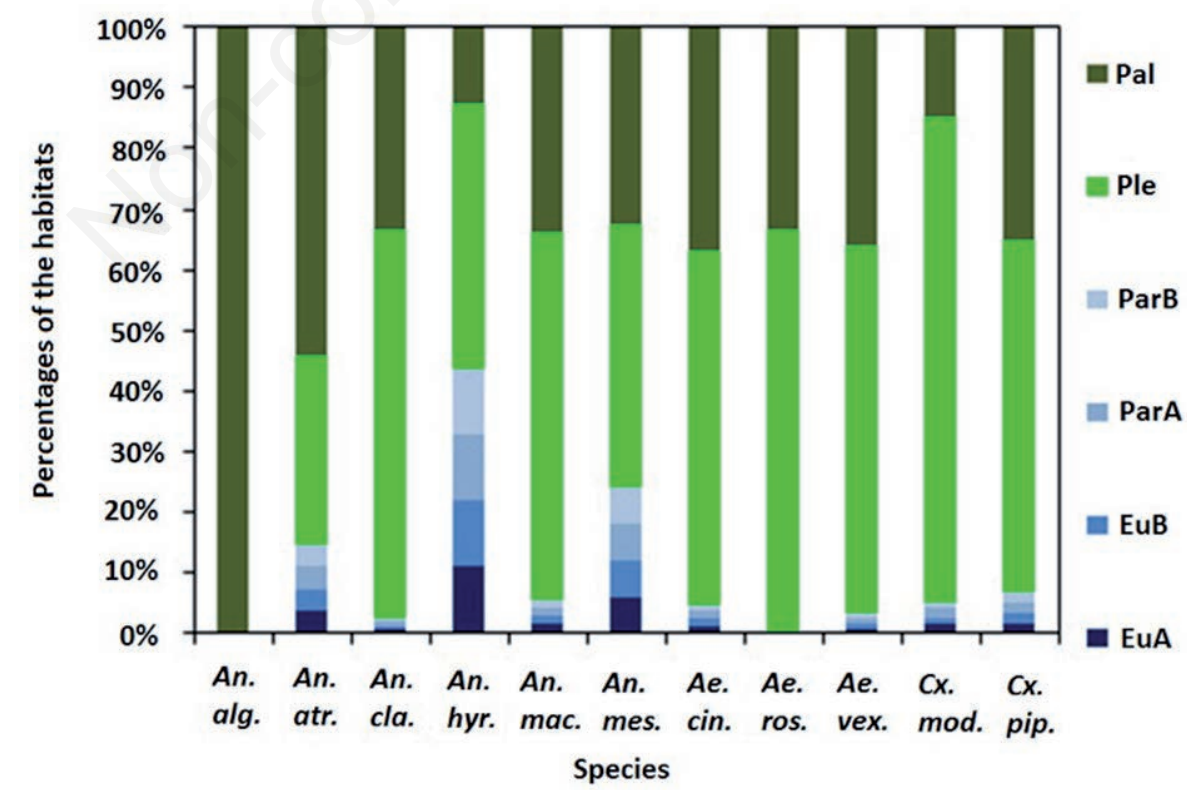

Fig. 2. Mean relative number of habitats where the mosquito larvae were found. EuA; eupotamon A; EuB, eupotamon B; ParA, parapotamon A; ParB, parapotamon B; Ple, plesiopotamon; Pal, paleopotamon. An. alg, Anopheles algeriensis; An. atr., Anopheles atroparvus; An. clav., Anopheles claviger; An. hyr., Anopheles hyrcanus; An. mac., Anopheles maculipennis; An. mes., Anopheles messeae; Ae. cin., Aedes cinereus; Ae. ros., Aedes rossicus; Ae. vex., Aedes vexans; Cx. mod., Culex modestus; Cx. pip., Culex pipiens pipiens. 
showed a pattern that was comparable to that of evenness (Fig. 6). Higher evenness values were related to higher transition numbers (significance of the correlation, $\mathrm{P}=0.039$ ).

\section{DISCUSSION}

Before river regulations, the continuous and natural change of the river bank system provided excellent ecological habitats for a number of aquatic organisms. The natural river bank dynamic was characterized by repeated floods that gave rise to the mosaic of the different habitats in the upper flow of the Danube in Hungary. The river occasionally left its bed, creating meanders and a rich channel network (Hohensinner et al., 2004). The slight fluctuation in the proportion of the different aquatic habitats indicates that a balance existed between the renewal, the formation and the terrestrialization of the aquatic habitats. This balance in the dynamics of the river system changed and declined abruptly after the river regulation in the $19^{\text {th }}$ century. The process culminated in an almost complete devastation of the marshes and swamps following the political and economic decisions to drain the wetlands in Hungary after the $2^{\text {nd }}$ World War. The building of the Gabčíkovo-Nagymaros Waterworks also caused the

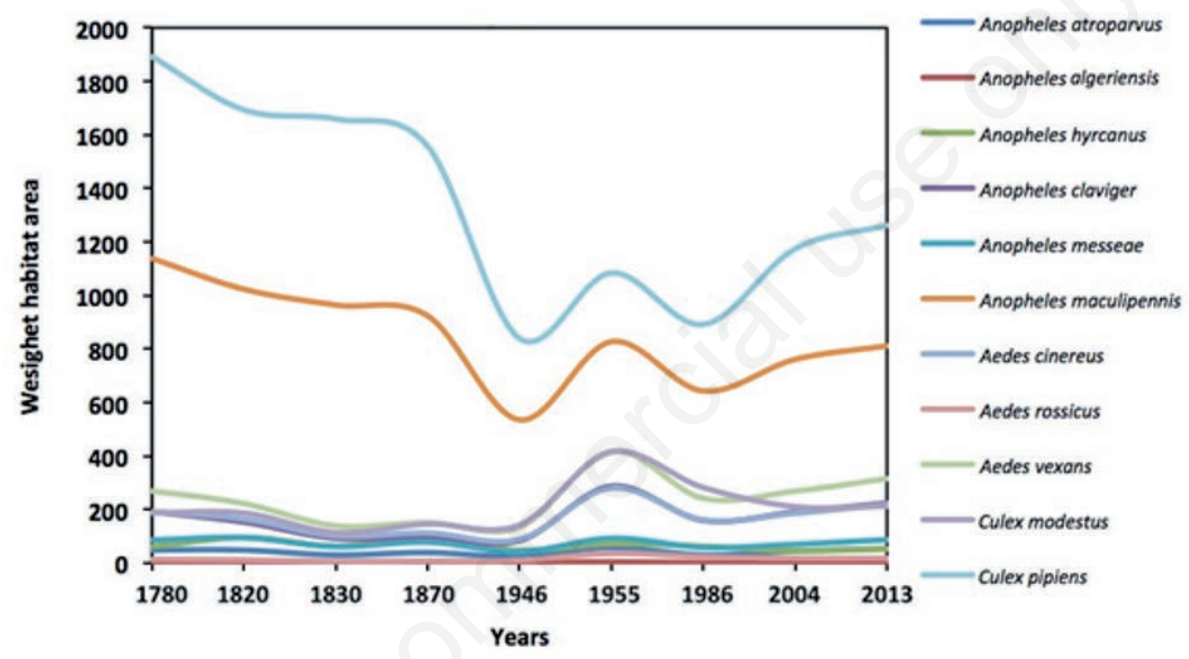

Fig. 3. Modeled habitat suitability-weighted area of the different mosquito species on absolute $H S W A$ value scale.

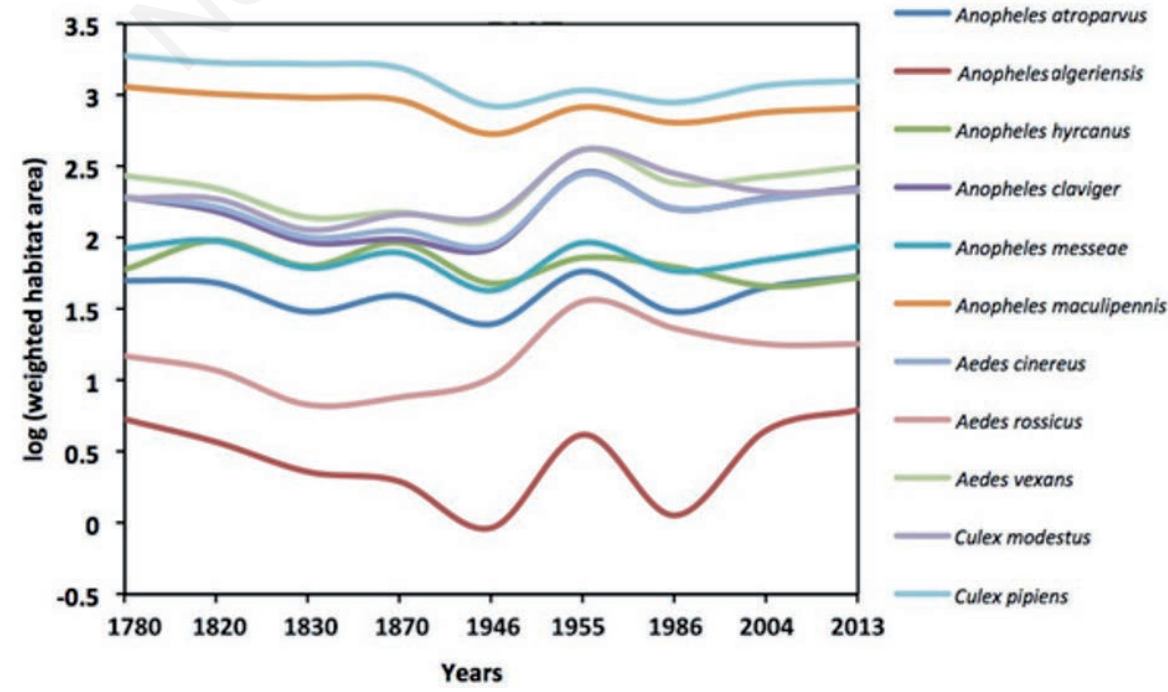

Fig. 4. Modeled habitat suitability-weighted area of the different mosquito species on $\log (H S W A)$ value scale. 
1790

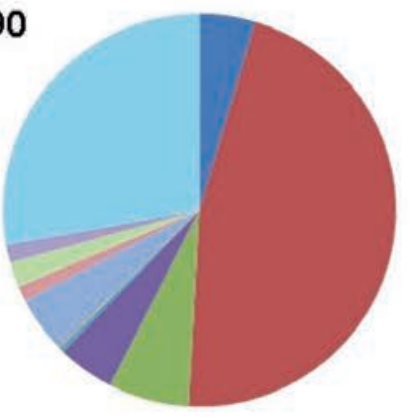

1830

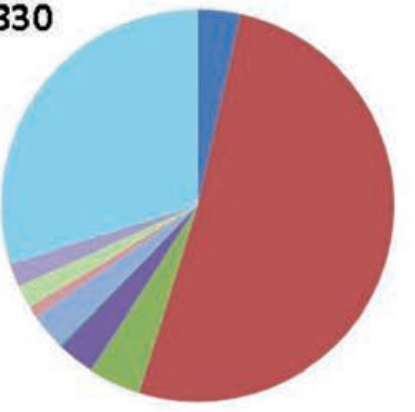

1946

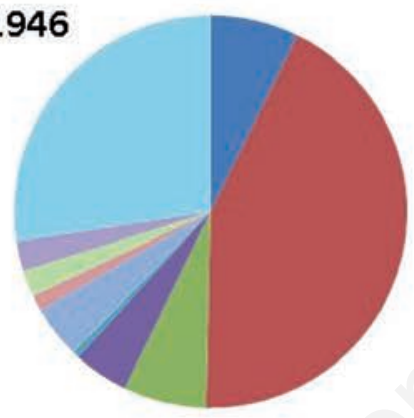

1986

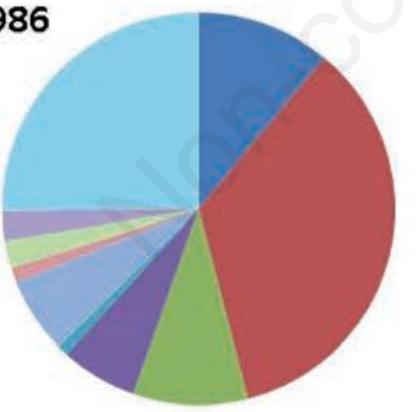

2013

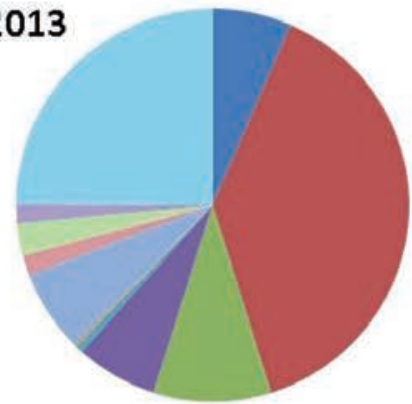

1820

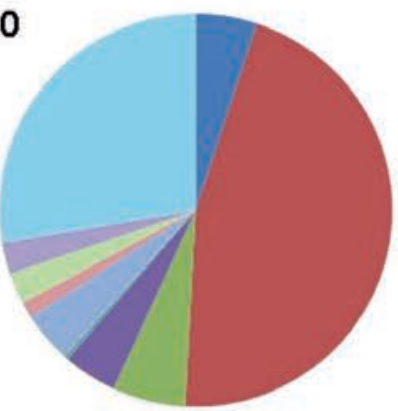

1870

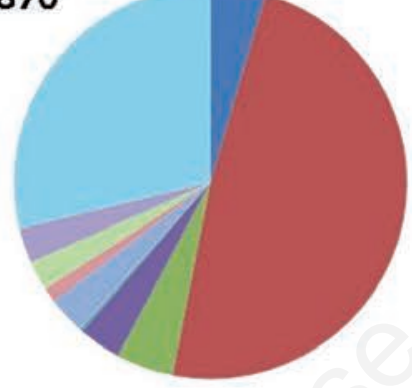

1955

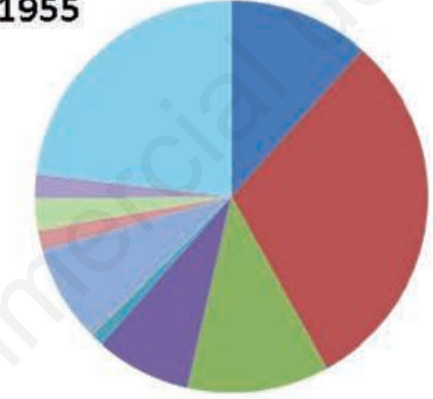

2004

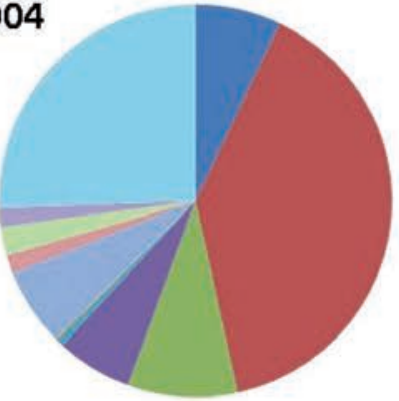

Anopheles maculipennis
Culex modestus

Culex

pipiens

\section{Aedes}

vexans

Aedes

cinereus

Aedes

rossicus

Anopheles algeriensis

Anopheles claviger

Anopheles atroparvus

Anopheles messeae

Fig. 5. The modeled \%HSWA values of the mosquito species. Anopheles hyrcanus was not marked in the chart diagram due to its low values. 
substantial modification of the river system completing the truncation of the Danube River. The area of eupotamal water bodies of the Szigetköz suffered a similar, significant decrease after the channelization as in case of the Austrian Marchland (Hohensinner, 2004). According to a few preliminary measurements of temperature and oxygen carried out on 14 August 2014 (Trájer et al., personal communication), the sequence from the eupotamon A, B to parapotamon $\mathrm{A}, \mathrm{B}$, plesiopotamon and paleopotamon can be ranked along an environmental gradient, namely from cool and oxigen rich, to warmer and oxygen poor river stream types. This successive order also coincides with the suitability of a stream type for mosquitoes, which is accordance with the findings of Tóth (2004).

Our habitat-matching models showed that, after the first river regulation, the number and the area of mosquito habitats increased until the mid- $20^{\text {th }}$ century. It may be debatable whether the regulated potamon ecotype corresponds to the original definitions by Tóth (2004). However, the present eupotamon A and B types continue to designate freshwaters with greater inflow, whereas plesiopotamon and paleopotamon are warmer, shallow and nutrient-rich water bodies with little or no flow. Our results are in accordance with the findings of Van̆hara (1991), who found that, after the extensive water management alterations on the southern Moravian Dyje and Morava rivers, the number and the diversity of the mosquito species of e.g. Culex and Anopheles in permanent water bodies increased. Nevertheless, the observations of Vaňhara (1991) spanned a shorter period, which could not reflect the medium- and short-term changes of the regulated potamon system. According to our model results, it is probable that, after the initial increase of the number and area of the shallow and permanent water bodies, the secondary changes of the clenched floodplain between the barriers and the deepening eupotamon A and B decreased the habitats suitable for the mosquito development.

We have to note that our aim was to characterize the area-based mosquito larva suitability of a given area, not to estimate long-term changes in the number of mosquitoes. The $H S W A$ value cannot approximate the abundance of a mosquito species because it is based on larval collection. This method can therefore only approximate the relative number of the larvae in water bodies. Though HSWA can be considered a rough estimation of the potential relative number of adult mosquitoes, the predatory pressure, meteorological conditions and flood events can substantially change the number of imagoes in a given period.

Since mosquitoes prefer the plesiopotamon-paleopotamon habitat types, the change of the weighted suitable habitats of the species inversely correspond with the area of the eupotamon A, B and parapotamon A, B riverbeds. Historically, since the Austrian regulation allowed filling the major part of the branches in the Danube system, the area of the suitable habitats began to decrease in the early 1800's. This caused the decline of the habitats of An. atroparvus, An. algeriensis, An. maculipennis, An. claviger, Ae. cinereus, Ae. rossicus, Ae. vexans and Cx. modestus, whereas the habitats of An. hyrcanus and An. messeae slightly increased. The large-scale regulation of the river,

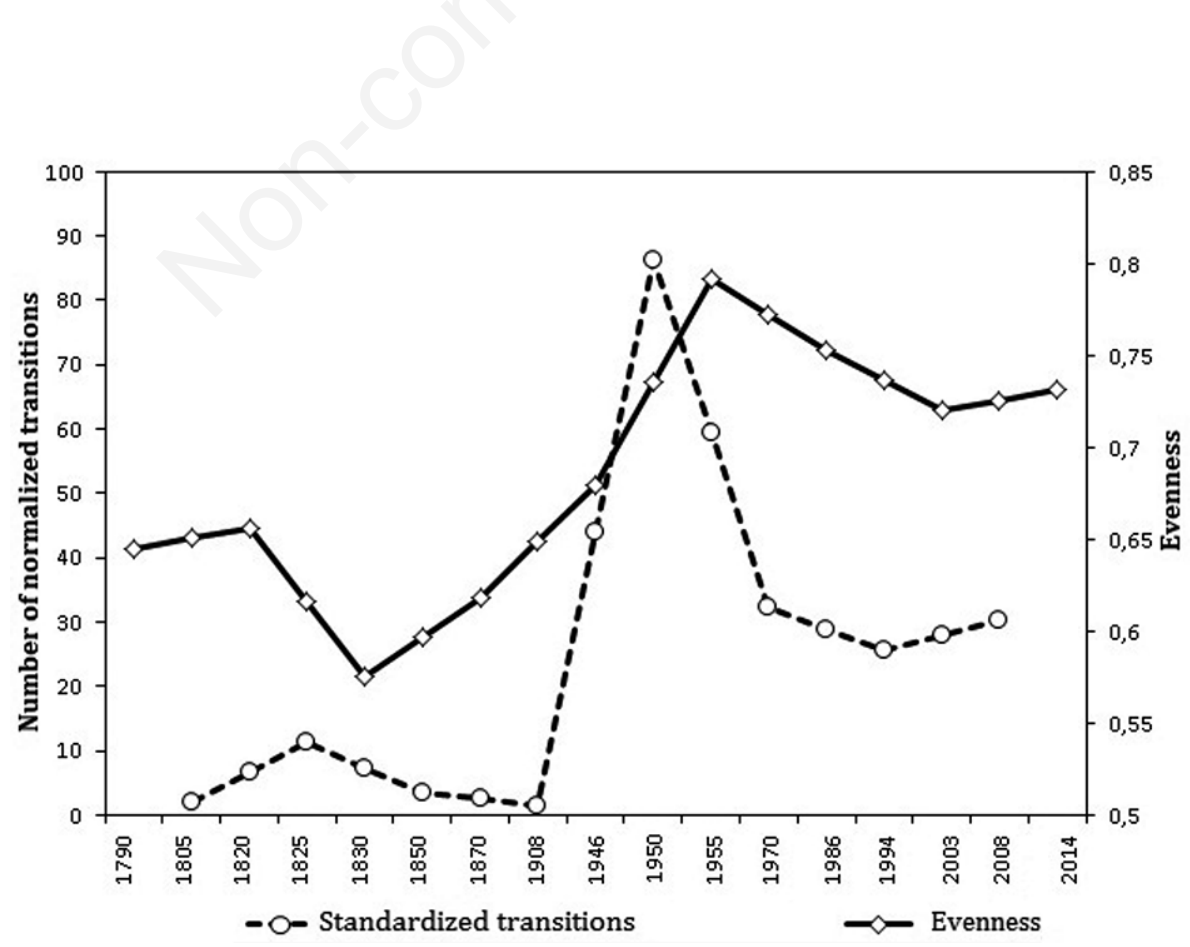

Fig. 6. Evenness values of the mosquito species and the frequency of the standardized transitions per year (explanations in the text). 
in 1870 , caused an increase in the area of the paleopotamon and plesiopotamon waters. In turn, according to our model, the regulation increased the habitats of $A n$. atroparvus, An algeriensis, An. claviger, Ae. cinereus, Ae. rossicus, Ae. vexans and $C x$. modestus. In the hydropower dam stage, the area of the mosquito suitable habitats increased due to the drastically decreasing groundwater level, which was advantageous particularly for $A n$. atroparvus, An algeriensis, An. messeae, An .claviger, Ae. cinereus and Ae. vexans.

Based on the modeled mean area-based suitability index, the relative abundance of the first four more frequent mosquito species showed the following order: $C x$. pipiens pipiens $>$ An. maculipennis $>$ Ae. vexans $>C x$. modestus. This ranking is somewhat similar to the countrywide frequency order of the mosquito species in Hungary, namely $C x$. pipiens pipiens $>$ Ae.vexans $>>C x$. modestus $>$ An. maculipennis. The HSWA value only characterize the mosquito suitability of the larger water habitats. However, since mosquitoes that develop in small water bodies like dendrotelmata or puddles were not considered, the $H S W A$ values do not specify the real potential abundance. Despite this limitations in the application of the method, the evenness based on HSWA values correlated significantly with the transition numbers. This is an ecologically interpretable and important result since functional richness and diversity can reach their peaks at moderate disturbance frequency and intensity (Biswas and Mallik, 2010). While the calculated evenness with a fixed species number reached its peak decades after the river regulation, the construction of the HPP did not increase the evenness values. It is plausible that the relatively slow and moderate modifications in the fluvial network was less drastical than the construction of the hydropower plan, resulting a gradual change that increased the area and the diversity of water habitats. Though the number of species was necessarilly fixed in this retrospective approach, other studies found a direct influence of disturbance on the evenness, without affecting the diversity of a studied group (Kimbro and Grosholz, 2006). In our study,the modifications of the river system triggered a chain of successional events that caused an increase in the evenness values and of the area more suitable for the development of the mosquito genera such as some member of Anopheles. These changes may increase the risk of an intensification in the recurrence of malaria. Ultimately, this risk may be also enhanced by the effects caused by climate change (Martens et al., 1999).

\section{CONCLUSIONS}

The quasi natural river dynamics may have a protective effect against the excessive habitat colonisation by mosquito species. Our findings suggest that the anthropogenic river bank modification strongly influenced the composition of the successive stages even after 60-70 years after the start of the regulation. These changes caused an increase in the mosquito-suitable habitats, although the effect was positive or negative depending on breeding-habitat preference of the different mosquito species. According to the model, the increase of the evenness of the mosquito fauna increased after the first major disturbance (the primary river regulation), maintaining constant high values since the mid- $20^{\text {th }}$ century. The disruption of the natural stream system caused the increase of the hematophagous mosquito diversity. The increasing areal extension of relatively warm and nutrient-rich water habitats had also positive effects on the rarest members of the mosquito fauna, such as the potential malaria mosquito vectors. The renaturalization of the river system may provide a long-term tool for the prevention of mosquitoborne diseases increasing the relative and absolute area of the eupotamon and parapotamon riverbeds within the floodplain. This effect is somewhat controversial since the increasing riverbed dynamics can also maintain the permanent regeneration of the paleopotamon and plesiopotamon riverbeds.

\section{ACKNOWLEDGEMENTS}

The study was supported by the TÁMOP 4.2.2.A11/1/KONV-2012-0064: Impact of extreme weather events on surface waters subproject.

\section{REFERENCES}

Ackerknecht EH, 1945. Malaria in the Upper Mississippi Valley 1760-1900. Bull. Med. Libr. Assoc. 33:372-373.

Amoros C, Roux AL, Reygrobellet JL, Bravard JP, Pautou G, 1987. A method for applied ecological studies of fluvial hydrosystems. Regul. River. 1:17-36.

Bartholy J, Pongrácz R, Gelybó Gy, 2007. Regional climate change expected in Hungary for 2071-2100. Appl. Ecol. Env. Res. 5:1-17.

Bartholy J, Pongrácz R, Gelybó G, Szabó P, 2008. Analysis of expected climate change in the Carpathian Basin using the PRUDENCE results. Quat. J. Hung. Met. Serv. 112:249-264.

Benedict MQ, Levine RS, Hawley WA, Lounibos LP, 2007. Spread of the tiger: global risk of invasion by the mosquito Aedes albopictus. Vector-Borne Zoonot. 7:76-85.

Biswas SR, Mallik AU, 2010. Disturbance effects on species diversity and functional diversity in riparian and upland plant communities. Ecology 91 28-35.

Brown H, Diuk-Wasser M, Andreadis T, Fish D, 2008. Remotely-sensed vegetation indices identify mosquito clusters of West Nile virus vectors in an urban landscape in the northeastern United States. Vector-Borne Zoonot.8:197-206.

Cailly P, Balenghien T, Ezanno P, Fontenille D, Toty C, Tran A, 2011. Role of the repartition of wetland breeding sites on the spatial distribution of Anopheles and Culex, human disease vectors in Southern France. Parasit. Vectors 6:65. 
Cajthaml J, 2013. Polynomial georeferencing method for old map series. Proc. $13^{\text {th }}$ SGEM GeoConference on Informatics, Geoinformatics and Remote Sensing 1:859-866.

Christensen N, Wood AW, Voisin N, Lettenmaier DP, Palmer $\mathrm{RN}, 2004$. The effects of climate change on the hydrology and water resources of the Colorado River basin. Climatic Change 62:337-363.

Dudgeon D, 1995. River regulation in southern China: ecological implications, conservation and environmental management. Regul. River. 11:35-54.

Farkas-Iványi, K, Gábor G, 2013. Historical changes of habitat dynamics in the Szigetköz Floodplain of the Danube River. Accessed on 20 September 2014. Available from: http://is.muni.cz/repo/1093491/FBFW2013_final.pdf

Farkas-Iványi K, Guti G, 2014. The effect of hydromorphological changes on habitat composition of the Szigetköz floodplain. Acta. Zool. Bulgar. 66: (s.7):117-121.

Farkas-Iványi, K, Trájer, A, 2015. The Influence of the river regulations on the aquatic habitats in River Danube, at the Bodak Branch-System, Hungary and Slovakia. Carpath. J. Earth Env. 10:235-245.

Fok É, 2007. The importance of dirofilariosis in carnivores and humans in Hungary, past and present. Mappe Parassitologiche 8:181-188.

Fürst H, 2006. The Hungarian-Slovakian conflict over the Gabčíkovo-Nagymaros Dams: an analysis.Accessed on: August 2014. Available from: http://www.columbia.edu/cu/ece/ research/intermarium/vol6no2/furst.pdf

Githeko, AK, Lindsay, SW, Confalonieri UE, Patz JA, 2000. GCC and vector-borne diseases: a regional analysis. Bull. World Health Organ. 78: 1136-1147.

Guti G, Potyó I, Gaebele T, Weiperth A, 2010. Ecological benchmarking of the aquatic habitat changes in the Szigetköz floodplain of the Danube. Proceedings $38^{\text {th }}$ IAD Conf., Dresden, Hungary. Available from: http://www.academia.edu/ download/30341757/Guti_et.al.Szigetkoz_floodplain_38.IA D.201.pdf

Hohensinner S, Habersack H, Jungwirth M, Zauner G, 2004. Reconstruction of the characteristics of a natural alluvial river-floodplain system and hydromorphological changes following human modifications: the Danube River (18121991). River Res. Appl.20:25-41.

Hohensinner S, Haidvogl G, Jungwirth M, Muhar S, Preis S, Schmutz S, 2005. Historical analysis of habitat turnover and age distributions as a reference for restoration of Austrian Danube floodplains. WIT Trans. Ecol. Envir. 3:489-502.

Hohensinner S, Jungwirth M, Muhar S, Schmutz S, 2011. Spatio-temporal habitat dynamics in a changing Danube River landscape 1812-2006. River Res. Appl. 27:939-955.

Jetten TH,Takken W, 1994. Anophelism without malaria in Europe. A review of the ecology and distribution of the genus Anopheles in Europe. Wageningen Agricultural University, Wageningen: $69 \mathrm{pp}$.

Kimbro DL, Grosholz ED, 2006. Disturbance influences oyster community richness and evenness, but not diversity. Ecology $872378-2388$.

Klobučar A, Merdic E, Benic N, Baklaic ŽL, Krčmar SA, 2006. First record of Aedes albopictus in Croatia. J. Am. Mosquito Contr. 22:147-148.

Kovats RS, Campbell-Lendrum DH, Mc Michel AJ, Woodward AH, Cox JS, 2001. Early effects of GCC: do they include changes in vector-borne disease? Philos. T. R. Soc. B 356:1057-1068.

Krisztalovics K, Ferenczi E, Molnar ZS, Csohan A, Ban E, Zoldi V , Kaszas K 2008. West Nile Virus infections in Hungary, August-September 2008. Euro Surveill.13:19030.

Lőrincz F, 1937. Malaria in Hungary. Riv. Malariol. 16:465-479.

Martens P, Kovats RS, Nijhof S, De Vries P, Livermore MTJ, Bradley DJ, Cox J, Mc Michael AJ, 1999. Climate change and future populations at risk of malaria. Global Environ. Chang. 9:S89-S107.

Mushinzimana E, Munga S, Minakawa N, Li L, Feng CC, Bian L, Kitron U, Schmidt C, Beck L, Zhou G, Githeko AK, Yan G, 2006. Landscape determinants and remote sensing of anopheline mosquito larval habitats in the western Kenya highlands. Malaria J.5:13.

Nilsson C, Reidy CA, Dynesius M, Revenga C, 2005. Fragmentation and flow regulation of the world's large river systems. Science 308:405-408.

Overgaard HJ, Ekbom B, Suwonkerd W, Takagi M, 2003. Effect of landscape structure on anopheline mosquito density and diversity in northern Thailand: implications for malaria transmission and control. Landscape Ecol. 18:605-619.

Scholte EJ, Schaffner F, 2007. Waiting for the tiger: establishment and spread of the Aedes albopictus mosquito in Europe, p. 241-260. In: W. Takken and B.G.J. Knols (eds.), Emerging pests and vector-borne diseases in Europe. Wageningen Academic Publishers.

Szénási Z, Vass A, Melles M, Kucsera I, Danka J, Csohán A, Krisztalovics K, 2003. Malaria in Hungary: origin, current state and principles of prevention. Orvosi hetilap 144:10111018.

Tóth S, 2004. [Magyarország csípôszúnyog-faunája (Diptera: Culicidae).6].[Book in Hungarian]. Somogy Megyei Múzeumok Igazgatósága, Kaposvár: 327 pp.

Töry K, 1952.[A Duna és szabályozása].[Book in Hungarian] Akadémiai Kiadó, Budapest: 454 pp.

Trájer AJ, Bede-Fazekas Á, Bobvos J,Páldy A, 2014. Seasonality and geographical occurrence of West Nile fever and distribution of Asian tiger mosquito. Quat. J. Hung. Met. Serv. 118:19-40.

Vaňhara J, 1991. A floodplain forest mosquito community after manmade moisture changes (Culicidae, Diptera). Regul. River 6:341-348.

Zittra C, Kocziha Z, Pinnyei S, Harl J, Kieser K, Laciny A, Eigner B, Silbermayr K, Duscher GG, Fok É, Fuehrer HP, 2015. Screening blood-fed mosquitoes for the diagnosis of filarioid helminths and avian malaria. Parasite. Vectors 8:1-6. 